\title{
Growth and Removal of Nitrogen and Phosphorus by a Macroalgae Cladophora glomerata Under Different Nitrate Concentrations
}

\author{
Aulia Ulfah Farahdiba*, Euis Nurul Hidayah*†, Gina Aprilliana Asmar* and Yadanar Win Myint** \\ *Department of Environmental Engineering, University of Pembangunan Nasional Veteran Jawa Timur, \\ Surabaya, Indonesia \\ **Nanotechnology Research Department, Department of Research and Innovation Yangon, \\ Ministry of Education, Myanmar \\ †Corresponding author: Euis Nurul Hidayah; euisnh@gmail.com
}

Nat. Env. \& Poll. Tech. Website: www.neptjournal.com

Received: 18-07-2019

Accepted: 05-10-2019

\section{Key Words:}

Macroalgae;

Cladophora glomerata;

Nitrate; Phosphate;

Kinetics

\begin{abstract}
Effectiveness of macroalgae was investigated for enhancing wastewater treatment processes. Bioremediation using macroalgae could remove nitrate and phosphate contaminants in the water where algae assimilate nitrogen and phosphorus and convert them to biomass. This study evaluates the effects of high nitrate concentration on the kinetics of cell growth during nitrate and phosphate removal by a macroalga Cladophora glomerata. The algal growth and nitrate removal from media containing initial nitrate concentrations of $5 \mathrm{mg} / \mathrm{L}$ to $400 \mathrm{mg} / \mathrm{L}$ were monitored in batch growth, whereas control media has no additional nitrate. Light exposure was kept for 12 and 20 hours. The purpose of this research was to find out the effect of various nitrate concentrations on nitrate and phosphate removal with macroalgal growth. Maximum growth kinetic reaches $\mu=0.075 /$ day in 20 hours light exposure with $100 \mathrm{mg} / \mathrm{L}$ initial nitrate concentration. Nitrate and phosphate reach about $90 \%$ removal rates on the fifth day. Nitrate concentration was not significantly affected by biomass growth (Pearson correlation: 0.295). But, phosphate concentration has a moderate correlation with macroalgae biomass (Pearson correlation: 0.533 ).
\end{abstract}

\section{INTRODUCTION}

In recent years, microalgae and macroalgae have been used in many environmental applications. Bioremediation using algal technology is believed to be a promising alternative technology. Several macroalgae have been suggested for the treatment of wastewaters with high nitrogen concentration (Cole et al. 2016, Ge \& Champagne 2017). Moreover, previous studies have shown that Cladophora glomerata has significant potential of bioremediation for wastewater treatment (Whitton 1970b).

Nitrogen in biogeological cycles produces compounds with different oxidation states like nitrate, nitrite, ammonium, organic nitrogen including amino acids, urea and proteins that are available to phytoplankton. Furthermore, high nitrate concentration will enhance the possibility of eutrophication. According to a study conducted by Lee et al. (2015), the nutrients with the complement of substrates greatly affected the optimization of macroalgae growth. Furthermore, if nutrient concentration is in excess in the water, macroalgal growth will be inhibited (Han et al. 2016).

Recently, C. glomerata became the most prodigal algae in the water streams. Eutrophication, caused by high nutrient content, will have a high influence of $C$. glomerata biomass with the optimal growth conditions of $0.07 \mathrm{mg} / \mathrm{L}$ phosphorous $(\mathrm{P}), 0.6 \mathrm{mg} / \mathrm{L}$ nitrate-nitrogen $\left(\mathrm{NO}_{3}-\mathrm{N}\right)$ and $0.2 \mathrm{mg} / \mathrm{L}$ ammonium nitrogen $\left(\mathrm{NH}_{4}-\mathrm{N}\right)$ (Whitton 1970a).

Algae can use nitrate $\left(\mathrm{NO}_{3}{ }^{-}\right)$, nitrite $\left(\mathrm{NO}_{2}{ }^{-}\right)$or ammonium $\left(\mathrm{NH}_{4}{ }^{+}\right)$as a nitrogen source. Nitrate $\left(\mathrm{NO}_{3}{ }^{-}\right)$is the main form of nitrogen in natural waters as well as a major nutrient for plant growth and algae (Putra \& Farahdiba 2018). The main sources of nitrogen in the water are nitrate and ammonium ions.

Phosphate is a form of phosphorus that can be used by plants. Phosphorus is also an essential nutrient for higher plants and algae and becomes a limiting factor for plants and algae (Selvaratnam et al. 2015). Orthophosphate $\left(\mathrm{PO}_{4}{ }^{-}\right.$ ${ }^{3}$ ) is an inorganic phosphorus source which is important for algal growth and can be produced by various forms of phosphorus-containing organic matter (Han et al. 2016). Macroalgal growth will also be affected by the duration of light exposure. Furthermore, among many environmental conditions, it was hypothesized that the macroalgae-bacteria system would respond to different photoperiod conditions in terms of an increase or decrease in the algal population and nitrogen concentration (Lee et al. 2015). 
Therefore, controlling the concentration of nitrate in water resources light exposure is required. Currently, there is limited data available on the toxicity of high concentration of nitrate and its influence on macroalgal biomass with $\mathrm{N}$ and $\mathrm{P}$ removal. In this study, the effects of high nitrate concentration and nitrate as the nitrogen source for the growth of Cladophora glomerata and nitrate and phosphate removal in the growth media have been investigated.

\section{MATERIALS AND METHODS}

The experiment was conducted at the Research Laboratory, Environmental Engineering UPNV. The study took place from the beginning of February to the end of May 2019, from the preparation stage to the analysis results. USEPA (1996) was followed to find nitrate concentration within the range finding test (RFT). Nitrate concentration used in this study was $100-1000 \mathrm{mg} / \mathrm{L}$. This preliminary study found that the critical macroalgae could live in nitrate concentration of 100$400 \mathrm{mg} / \mathrm{L}$ (Farahdiba et al. 2019). When nitrate concentration was higher than $400 \mathrm{mg} / \mathrm{L}$, macroalgae became withered and yellow immediately.

Batch scale experiment was conducted with $300 \mathrm{~mL}$ of laundry wastewater sample in a glass jar within 5 days with 5 different nitrate concentrations. Each reactor was spiked with macroalgae $C$. glomerata to remove high nitrate and phosphate concentration. This research was conducted for 5 days with additional light from a LED lamp of 20 watts (or 3600 lux) for 12 and 20 hours illumination. Nitrate and phosphate were determined according to Standard Methods (González-Camejo et al. 2018).

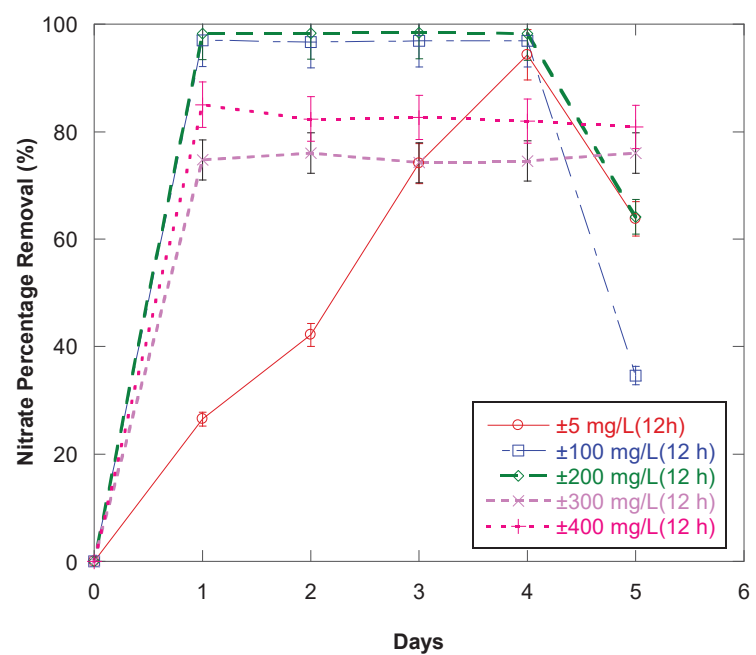

Fig. 1: Nitrate removal with $12 \mathrm{~h}$ light exposure by macroalgae under five nitrate concentration levels within five days.
Nitrate concentration used from RFT test was $0-400$ $\mathrm{mg} / \mathrm{L}$. Macroalgae spiked with the water laden with 5 different concentrations: a) $5 \mathrm{mg} / \mathrm{L}$ (control reactor, without additional nitrate); b) $100 \mathrm{mg} / \mathrm{L}$; c) $200 \mathrm{mg} / \mathrm{L}$; d) $300 \mathrm{mg} / \mathrm{L}$, and e) $400 \mathrm{mg} / \mathrm{L}$.

Initial macroalgae biomass was measured as the average of 10 samples weighing from fresh algal sample to dry weight of macroalgae biomass at $105^{\circ} \mathrm{C}$ for 4 hours (Horwitz \& Chemists 2000). The preliminary test was to determine the initial macroalgae biomass value obtained from drying 10 macroalgae samples with the same weight. The dry weight results of the 10 macroalgae samples were averaged and the initial biomass yield was $1332.9 \mathrm{mg} / \mathrm{L}$ (Ge \& Champagne 2017). This data becomes the baseline of the algae biomass within sampling on the day.

In this study, the calculated specific growth rate $\mu /$ day in the exponential phase of algal growth was measured by using Eq. 1 (Issarapayup et al. 2009, Zhu et al. 2013)

$$
\mu(/ \text { day })=\ln \left(N_{2}-N_{1}\right) /\left(t_{2}-t_{1}\right)
$$

where $\mathrm{N} 1$ and $\mathrm{N} 2$ are defined as dry biomass $(\mathrm{mg} / \mathrm{L})$ at time $t_{1}$ and $t_{2}$, respectively.

The biomass productivity (P) was calculated according to the formula given in Eq. 2.

$$
P\left(\frac{m g}{L} \cdot d a y\right)=\left(D W_{i}-D W_{0}\right) /\left(t_{i}-t_{0}\right)
$$

Where, DWi and DW0 are dry biomass $(\mathrm{mg} / \mathrm{L})$ at time $\mathrm{t}_{\mathrm{i}}$ and $\mathrm{t}_{0}$ (initial time), respectively.

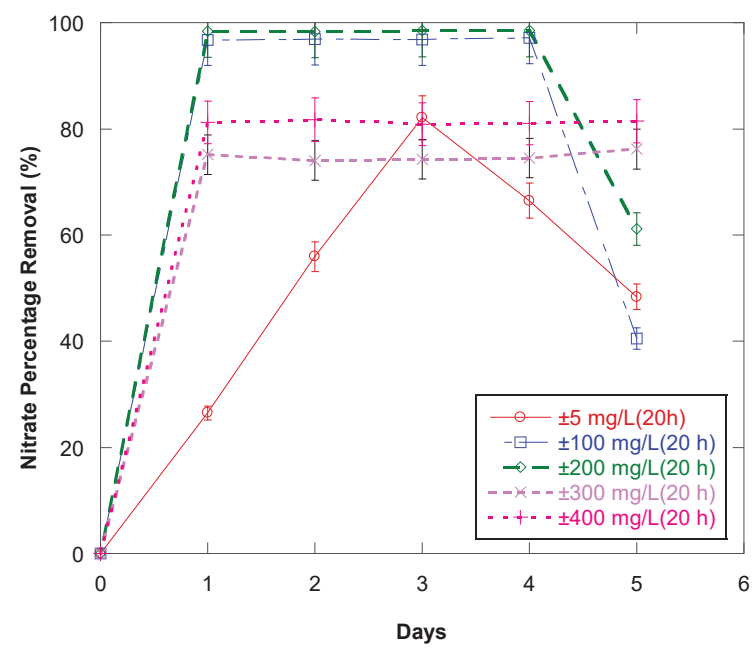

Fig. 2: Nitrate removal with $24 \mathrm{~h}$ light exposure by macroalgae under five nitrate concentration levels within five days. 
Data analysis was performed with EXCEL (Microsoft Office Enterprise 2010) and Minitab 2016 for Windows and correlation was determined wherever applicable.

\section{RESULT AND DISCUSSION}

\section{Effect of Nitrate Concentration and Light Exposure on Nitrate Removal}

Fig. 1 shows that the nitrate dramatically decreased within 5 days in all the experiments. Furthermore, the removal in the treatment with an initial nitrate concentration of $5 \mathrm{mg} / \mathrm{L}$ (control) was slowed down as compared to other nitrate concentrations. However, the control reactor has a different downward trend. Other reactors showed an increase slightly from day 1 to 4 and a reduction on the fifth day.

In the first day's observation, the maximum nitrate reduction was $98.26 \%$ with the initial nitrate concentration of $200 \mathrm{mg} / \mathrm{L}$. When the test came to the fourth day, $94.32 \%$, $96.89 \%, 98.21 \%, 74.53 \%$ and $81.97 \%$ were accordingly removed from 5, 100, 200, 300 and $400 \mathrm{mg} / \mathrm{L}$ nitrate cultures. Nitrate in 0,100 and $200 \mathrm{mg} / \mathrm{L}$ increased on the first day and dropped on the fifth day; while in 300 and $400 \mathrm{mg} / \mathrm{L}$, it increased on the first day and stabilized until the end of the experiment.

Nitrate removal efficiency in 20-hour irradiation reactor could be seen in Fig. 2, which has a similar trend with 12 hours of exposure. Moreover, in $5 \mathrm{mg} / \mathrm{L}$ nitrate concentration with 20 hours, the faster removal efficiency was reached than the 12 hours exposure (on the third day); while in the following days it reduced significantly.

In the four days of observation, the maximum nitrate reduction of $98.18 \%, 98.51 \%, 74.26 \%$, and $81.07 \%$ was accordingly removed from 100, 200, 300 and $400 \mathrm{mg} / \mathrm{L}$.

The significantly high removal efficiency of nitrate was achieved among all the treatments (Figs. 1 and 2). Based on Fig. 1 and Fig. 2, the nitrate level in the test reactor is sufficient to reach a very high removal efficiency in nitrate on days 1 to 4 and decreases on the last day. Whereas, in the control reactor it gradually increases from days 1 to 4 and began to fall on the fifth day. Increased level of nitrate reduction is because the algae have well adapted to the day and night period. This has increased the dissolved organic carbon in water through active photosynthesis which is strongly correlated with the bacterial system (Kouzuma \& Watanabe 2015, Lee et al. 2015, Unnithan et al. 2014). Throughout the experiment, $\mathrm{pH}$ condition is in the normal range, which indicates that nitrification and denitrification were not the main processes responsible for nitrogen removal. Since the mean $\mathrm{pH}$ in the reactor was less than 8.5, ammonia volatilization through the surface might have been limited (Derabe-Maobe 2014).

In addition, increased nitrate concentration could be caused by the release of cellular nutrients by microalgae. Macroalgae lysis during the death phase can also increase nitrates (Ma et al. 2014).

The average nutrient removal rates were not significantly different among the two photoperiod conditions during the experiment as the 12 or 20 hours time exposure could be partially attributed to the high adaptability of algae in controlling carbon assimilation and respiration (Ma et al. 2014).

\section{Effect of Nitrate Concentration and Light Exposure Variation on Phosphate Removal}

The phosphate removal with 12 hours light exposure in this study was measured and shown in Fig. 3. On the first day until fourth day phosphate reduction was relatively stable. Four days were assumed to be the optimum time for macroalgae to remove phosphate. On the last day of the main study (day 5 ), it was found that the percentage of phosphate reduction began to decline, the condition was considered to be the point or time of saturation of macroalgae in remaking phosphate.

Furthermore, this trend is similar to the 20 hours trend. The phosphate removal is not significantly directly affected by light illumination. From the two irradiation periods, it can be seen that the highest per cent reduction is achieved by macroalgae on the fourth day, which is considered as the optimum macroalgae time in absorbing phosphate.

Table 1: Growth parameters of macroalgae under five nitrate concentrations and light exposure in 5 days.

\begin{tabular}{|llllll|}
\hline Initial nitrate concentration $(\mathrm{mg} / \mathrm{L}$ nitrate) & \multicolumn{2}{l}{ Specific growth rate $\mu$ (/day) } & \multicolumn{2}{ll}{ Biomass increase $(\mathrm{mg} / \mathrm{L})$} & \multicolumn{2}{c|}{ Biomass productivity (mg/L.day) } \\
\hline & $12 \mathrm{~h}$ & $24 \mathrm{~h}$ & $12 \mathrm{~h}$ & $24 \mathrm{~h}$ & $12 \mathrm{~h}$ \\
5 (Control) & 0.009 & 0.014 & 61.433 & 96.767 & 18.937 \\
100 & 0.056 & 0.075 & 431.433 & 604.767 & 44.321 \\
200 & 0.035 & 0.0262 & 259.766 & 186.767 & 35.165 \\
300 & 0.027 & 0.0261 & 194.767 & 185.433 & 31.176 \\
400 & 0.011 & 0.0264 & 77.767 & 187.767 & 20.558 \\
\hline
\end{tabular}


The four days observation on both the hours' exposure, showed that the maximum phosphate reduction of $92.72 \%$, $92.82 \%, 92.72 \%, 92.57 \%, 92.77 \%$ was accordingly achieved from 5, 100, 200, 300 and $400 \mathrm{mg} / \mathrm{L}$ of nitrate concentration.

Reduced phosphate levels in microalgae media are caused by the use of phosphate as a nutrient for microbial growth (Fig. 3). Phosphate functions are energy metabolism, protein synthesis, regulation of starch and starch production, formation of proteins, carbohydrates, cell structures and cell membrane stabilizers (Grover \& Mar 2008). Decreasing in phosphate levels is due to the increasing number of macroalgae which increases the requirement for phosphate (Tang et al. 2016).

The efficiency of the resulting phosphate reduction varies depending on the composition of the media and environmental conditions such as initial nutrient concentration, irradiation time, and the ratio of nitrate:phosphate, light or dark. Moreover, the process of decreasing of pollutants in wastewater using aquatic plants is a collaboration between plants and microbes associated with these plants (Lee et al. 2015).

\section{Macroalgae Growth Kinetics}

Table 1 shows the growth kinetics and biomass productivity in this experiment with 12 hours and 20 hours of light exposure. Biomass testing can be used as a reference to determine the growth of macroalgae by dry weight biomass. Macroalgae growth can be observed by determining the growth phase which is divided into four phases which include the lag, exponential, stationary and lysis (Zhu et

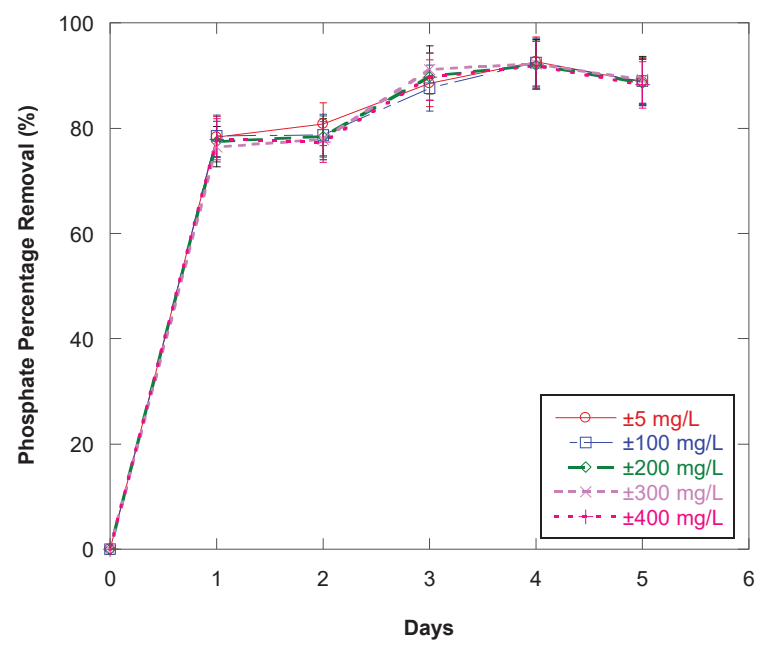

Fig. 3: Phosphate removal with $12 \mathrm{~h}$ and $20 \mathrm{~h}$ light exposure by macroalgae under five nitrate concentration levels in five days. al. 2013, Cahyonugroho et al. 2020). The results in Fig. 4 show the macroalgae growth obtained from the five different nitrate concentrations. All reactors have increased biomass growth on the first day. The results of biomass growth in the reactor with 20:4 irradiation were found to have similar trends. Furthermore, the specific growth rate in 12 and 24 hours has a high correlation, with the Pearson correlation coefficient of 0.879 .

The macroalgae, cultivated in the media with the nitrate concentration of 5,100,200, 300 and $400 \mathrm{mg} / \mathrm{L}$ had an exponential stage and then fluctuate in the stationary phase with 12 to 20 hours light exposure (Fig. 4).

Statistical analysis was conducted to determine the correlation between biomass concentration and N, P concentrations using Pearson correlation value. Biomass is greatly affected by phosphate concentration (Pearson value: 0.533 in 12 and 20 hour). Nevertheless, nitrate concentration has a lower correlation value ( 0.295 in 12 and 20 hour).

However, the exponential growth in the culture with all the reactors lasted for one to two days, following a predicted lag phase, which lasted for about 4 days. In five days, algal cells reduce in all the nitrate concentrations; in order with similar trends with a lower removal efficiency of $\mathrm{N}$ and P. It was predicted that on the fifth day, macroalgae would be in the stationary-lysis stage. In this study, the lack of a visible lysis phase was because the cultivation period was short. Research by Taziki et al. (2016) showed that the completed algal life stage would appear after about 12 days. However, the algal life stage is dependent on the algal species, nutrient and environmental condition.

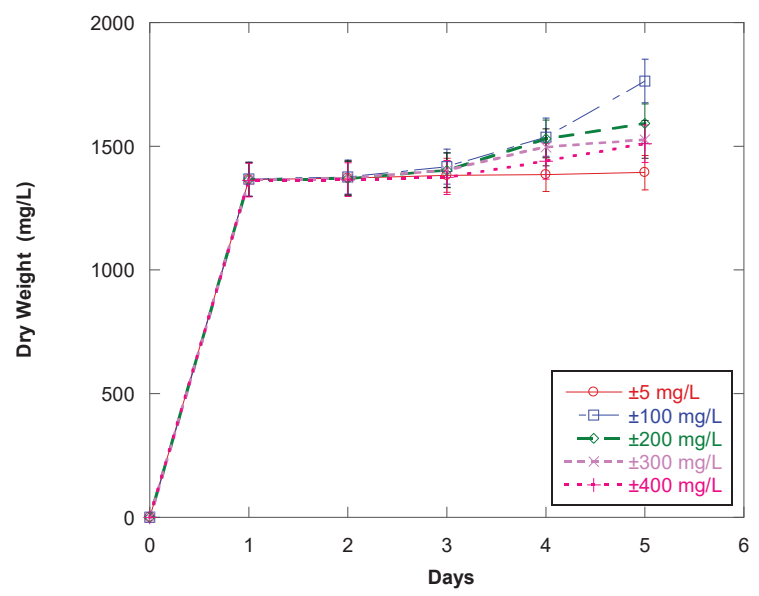

Fig. 4: Growth curves for macroalgae (Cladophora glomerata) grown under five nitrate concentration levels in five days. 
The specific growth rate $(\mu)$ of macroalgae in 5, 100, 200,300 and $400 \mathrm{mg} / \mathrm{L}$ nitrate concentration was 0.024 , $0.075,0.0262,0.0261$ and 0.0264 day/L respectively. The final biomass productivity increase significantly at $100 \mathrm{mg} / \mathrm{L}$ which was the highest, reaching to $60.88 \mathrm{mg} / \mathrm{L}$.day, while the culture in 5 and $400 \mathrm{mg} / \mathrm{L}$ nitrate showed the lowest biomass increase (30 and $29 \mathrm{mg} / \mathrm{L}$.day, respectively). The biomass productivity in this study was lower than that in the research by Zhu et al. (2013).

\section{CONCLUSION}

The macroalgae Cladophora glomerata has high removal efficiency to reduce nitrate and phosphate concentration in high nitrate concentration, but macroalgae biomass was not directly influenced by nitrate concentration. Moreover, the reactor has low growth kinetics and biomass productivity. This is probably the complication in the algae reactor because of various factors which affect the macroalgae performance to remove contaminants in the water.

\section{ACKNOWLEDGEMENT}

This study was a part of funding supported by grants from Directorate of Research and Community Service, Directorate General of Research Development, Ministry of Research Technology and Higher Education of Indonesia. This research was carried out under contract No. 201/SP2H/LT/ DRPM/2019.

\section{REFERENCES}

Cahyonugroho, O.H., Yuniawati, D.D. and Hidayah, E.N. 2020. Kinetics of Chlorella sp. growth models in reducing $\mathrm{CO}_{2}$ emission. Rasayan Journal of Chemistry, 12(4): 2306-2310.

Cole, A. J., Neveux, N., Whelan, A., Morton, J., Vis, M., de Nys, R. and Paul, N. A. 2016. Adding value to the treatment of municipal wastewater through the intensive production of freshwater macroalgae. Algal Research, 20: 100-109.

Derabe-Maobe, H. 2014. High Rate Algal Pond for Greywater Treatment in Arid and Semi-Arid Areas. Hokkaido University.

Farahdiba, A.U., Hidayah, E.N. and Asmar, G. A. 2019. Utilization of Cladophora glomerata for organic substance removal in laundry wastewater with artificial light exposure. Journal BIOTA, 5(2).

Ge, S. and Champagne, P. 2017. Cultivation of the marine macroalgae Chaetomorpha linum in municipal wastewater for nutrient recovery and biomass production. Environmental Science and Technology, 51(6): 3558-3566.
González-Camejo, J., Barat, R., Pachés, M., Murgui, M., Seco, A. and Ferrer, J. 2018. Wastewater nutrient removal in a mixed microalgae-bacteria culture: Effect of light and temperature on the microalgae-bacteria competition. Environmental Technology (United Kingdom), 39(4): 503-515.

Grover, J.P. and Mar, N. 2008. phosphorus-dependent growth kinetics of 11 species of freshwater algae phosphorus-dependent growth lunatics of 11 species of freshwater algae. Limnology, 34(2): 341-348.

Han, L., Xu, B., Qi, F. and Chen, Z. 2016. Effect of nitrogen/phosphorus concentration on algal organic matter generation of the diatom Nitzschia palea: Total indicators and spectroscopic characterization. Journal of Environmental Sciences (China), 47: 130-142.

Horwitz, W. 2000. Official Methods of Analysis of AOAC. Association of Official Analytical Chemists, Washington, DC.

Issarapayup, K., Powtongsook, S. and Pavasant, P. 2009. Flat panel airlift photobioreactors for cultivation of vegetative cells of microalga Haematococcus pluvialis. Journal of Biotechnology, 142(3-4): 227-232.

Kouzuma, A. and Watanabe, K. 2015. Exploring the potential of algae/ bacteria interactions. Current Opinion in Biotechnology, 33: 125-129.

Lee, C. S., Lee, S. A., Ko, S. R., Oh, H. M. and Ahn, C. Y. 2015. Effects of photoperiod on nutrient removal, biomass production, and algal-bacterial population dynamics in lab-scale photobioreactors treating municipal wastewater. Water Research, 68: 680-691.

Ma, X., Zhou, W., Fu, Z., Cheng, Y., Min, M., Liu, Y. and Ruan, R. 2014. Effect of wastewater-borne bacteria on algal growth and nutrients removal in wastewater-based algae cultivation system. Bioresource Technology, 167: 8-13.

Putra, A.H. and Farahdiba, A.U. 2018. Performance of algae reactor for nutrient and organic compound removal. In: International Conference on Science and Technology (ICST 2018) (pp. 119-125), Atlantis Press.

Selvaratnam, T., Pegallapati, A., Montelya, F., Rodriguez, G., Nirmalakhandan, N., Lammers, P.J. and van Voorhies, W. 2015. Feasibility of algal systems for sustainable wastewater treatment. Renewable Energy, 82: 71-76.

Tang, C.C., Zuo, W., Tian, Y., Sun, N., Wang, Z. W. and Zhang, J. 2016. Effect of aeration rate on performance and stability of algal-bacterial symbiosis system to treat domestic wastewater in sequencing batch reactors. Bioresource Technology, 222: 156-164.

Taziki, M., Ahmadzadeh, H. and A. Murry, M. 2016. Growth of Chlorella vulgaris in high concentrations of nitrate and nitrite for wastewater treatment. Current Biotechnology, 4(4): 441-447.

Unnithan, V. V., Unc, A. and Smith, G.B. 2014. Mini-review: A priori considerations for bacteria-algae interactions in algal biofuel systems receiving municipal wastewaters. Algal Research, 4(1): 35-40.

USEPA 1996. Ecological Effects Test Guidelines Aquatic Plant Toxicity Test Using Lemna spp., Tiers I and II. Environmental Protection, (January).

Whitton, B. A. 1970a. Biology of Cladophora in freshwaters. Water Research, 4(7): 457-476.

Whitton, B. A. 1970b. Review Paper: Biology of Cladophora. Water Research, 4: 457-476.

Zhu, L., Wang, Z., Shu, Q., Takala, J., Hiltunen, E., Feng, P. and Yuan, Z. 2013. Nutrient removal and biodiesel production by integration of freshwater algae cultivation with piggery wastewater treatment. Water Research, 47(13): 4294-4302. 